\title{
Mononuclear cell metallothionein mRNA levels in human subjects with poor zinc nutrition
}

\author{
Chong-Suk Kwon ${ }^{1}$, Aggeliki M. Kountouri ${ }^{2}$, Claus Mayer ${ }^{2}$, Margaret-Jane Gordon², \\ In-Sook Kwun ${ }^{1}$ and John H. Beattie ${ }^{2} *$ \\ ${ }^{1}$ Department of Food Science and Nutrition, Andong National University, Kyungpook, 760-749, South Korea \\ ${ }^{2}$ Division of Cellular Integrity, Rowett Research Institute, Greenburn Road, Bucksburn, Aberdeen AB21 9SB, UK
}

(Received 24 May 2006 - Revised 17 August 2006 - Accepted 21 August 2006)

\begin{abstract}
Human zinc deficiency is thought to be prevalent worldwide, particularly in populations with diets low in zinc and animal protein and high in inhibitors of zinc absorption, such as phytic acid. Confirmation of zinc deficiency is, however, difficult in the absence of a reliable and sensitive marker of zinc status. Under controlled conditions, T-lymphocyte metallothionein-2A (MT-2A) mRNA levels change in relation to zinc status and the objective of the present study was to investigate whether these transcript levels could be related to dietary zinc intake, plasma zinc or other biochemical parameters influenced by, or influencing, zinc metabolism in human subjects likely to be zinc deficient. Rural Koreans ( $n$ 110, age 50-80 years) with a range of zinc and phytic acid dietary intake were recruited for the study and blood samples were analysed for plasma zinc, HDL, LDL, $\alpha$-tocopherol and thiobarbituric acid reactive substances, mononuclear cell (MNC) MT-2A mRNA, serum protein and albumin, and blood haematocrit, $\mathrm{Hb}$ and glucose. Multiple correlation and principal component analysis showed a significant negative correlation between plasma zinc and MNC MT-2A mRNA levels. Female subjects had higher MT-2A transcript levels than males and MT-2A mRNA levels tended to increase with age. There was no significant association between dietary zinc intake or any index of zinc intake relating to dietary inhibitors of zinc absorption. It is concluded that MNC MT-2A mRNA levels cannot be used to predict poor zinc nutrition.
\end{abstract}

Mononuclear cells: Metallothionein: Zinc nutrition: Zinc status

The WHO estimates that over two billion people worldwide may be zinc deficient (World Health Organization, 2002). This assessment is based on food availability data not on zinc status, which is difficult to assess because of the lack of reliable status markers (Hambidge, 2003). Several diagnostic markers of zinc status have been evaluated, including levels of plasma zinc, plasma alkaline phosphatase, plasma thymulin and hair/nail zinc (McKenzie, 1979; Wood, 2000). All of these markers have proven unsatisfactory for various reasons, but the greatest disadvantages seem to be that they are not specific for zinc deficiency and they have limited sensitivity. Metallothionein (MT) was proposed as a marker of zinc status many years ago (Grider et al. 1990; King, 1990) due to the sensitivity and magnitude of its induction by zinc. Zinc-deficient rats had substantially lower plasma levels of MT (Sato et al. 1984) and MT levels in human erythrocytes decreased in experimental zinc deficiency (Grider et al. 1990; Thomas et al. 1992). The problem with measuring plasma MT was the lack of available immunoassays with sufficient sensitivity and specificity. Analysis of erythrocyte MT was confounded by the observation that most of the MT was concentrated in the reticulocyte fraction, and that changes in erythropoesis could therefore influence total erythrocyte MT levels (Robertson et al. 1989). Mononuclear cell (MNC) MT mRNA levels measured by competitive RT-PCR methods have been shown to be positively correlated with zinc status (Allan et al. 2000; Cao \& Cousins, 2000), and the development of real-time RT-PCR has improved the ease with which this target can be quantified.

There are several dietary factors that can affect zinc absorption, among the most notable being phytate and calcium, which decrease absorption (Krebs, 2000; Lonnerdal, 2000). Molar ratios of $>20$ for the phytate: $\mathrm{Zn}$ content and $>200$ for the phytate $\times \mathrm{Ca}: \mathrm{Zn}$ content of diets have been recognized as likely to induce zinc deficiency (Ruz et al. 1991), and the diets of some population groups throughout the world exceed these threshold ratios. Indeed, mean values of 40 and 400 have been recorded for phytate: $\mathrm{Zn}$ and phytate $\times \mathrm{Ca}: \mathrm{Zn}$ ratios, respectively, in the diets of rural Koreans (Lee et al. 2004). Plasma alkaline phosphatase levels in 176 volunteers at risk of zinc deficiency according to their zinc, phytate and calcium intakes, were found to be considerably lower than the reference range, although plasma zinc was not lower than the respective reference range. Although the utility of quantifying T-lymphocyte MT-2A mRNA for the assessment of zinc status had been demonstrated in a controlled intervention study (Allan et al. 2000), its application to the assessment of zinc status in population groups has not been evaluated. We proposed therefore to measure MT-2A mRNA levels in mononuclear leucocytes from rural Korean subjects who were likely to show a range of zinc intakes and status. Taking advantage of samples from an

Abbreviations: MNC, mononuclear cell; MT, metallothionein.

* Corresponding author: Dr John H. Beattie, fax +44 (0)1224 716629, email J.Beattie@ rowett.ac.uk 
on-going large study relating nutritional status to health in different Korean localities, we identified a sub-group of individuals suitable for the present study. Our major objectives were twofold: (1) to investigate the range and variation of MT gene expression in MNC from subjects in a population and to relate the MT levels to variable factors such as age and sex, and (2) to investigate whether dietary zinc intake and plasma zinc is related to MNC MT expression.

\section{Methods and materials}

\section{Volunteer recruitment}

Subjects were recruited as part of the Public Medical Center Health Promotion Program Project, from fifteen rural localities in the Andong area of South Korea. Recruitment was achieved by sending an information postcard to the residents of each area and those wishing to join the project were accepted, subject to meeting the inclusion criteria. The final number of volunteers recruited to the study was around 1700, and they were assumed to be representative of the whole population. Subjects were aged 50-80 years with a BMI within the normal range (18-26). A sub-sample of 110 volunteers from seven localities were selected for the present study on the basis of their zinc intake. This sub-population was representative of the range of zinc intakes found in the larger study group and contained both male and female volunteers. Exclusion criteria included any clinical signs of chronic disease or infections and any long-term medication or supplementation. Ethical permission for the present study was granted by the Andong Public Medical Center Ethical Committee.

Body weight ranged from 58 to $66 \mathrm{~kg}$ for men and 51 to $59 \mathrm{~kg}$ for women. Height ranged from 162 to $167 \mathrm{~cm}$ and from 146 to $155 \mathrm{~cm}$ for men and women, respectively, and BMI from 21.94 to 24.40 for males and from 23.90 to 25.61 for females. BMI was calculated by dividing body weight in $\mathrm{kg}$ by (height $)^{2}$ in $\mathrm{m}$. The volunteer age and sex for each locality are presented in Table 1.

\section{Health status and dietary assessment}

For screening medical status a general questionnaire was used to obtain information on the medical history of subjects and their family history, including the nature of any disease and its duration. A routine physical examination was also made by medical examiners of the Andong Public Medical Center Health Promotion Program.

A FFQ was used for estimation of the intakes of zinc, calcium, phytate and other nutrients. The FFQ, which contained thirtyeight food items, included the major food sources and major zinc-containing food items which are commonly consumed by Koreans during the four seasons of each year. FFQ data were correlated with $24 \mathrm{~h}$ recall information to validate the FFQ method.

Nutrient intakes were calculated using Computer Aided Nutritional Analysis Program, version 2.0 (CAN Pro 2.0, Korea Nutrition Society, Seoul, South Korea). Intake for zinc and phytate, which are not included in the CAN Pro 2.0 program, were analysed using food composition tables, databases, a cross-referenced index and various values from the literature (Korean Food \& Drug Association, 1996; Korean Food and Drug Safety Section, 2002; Kwun \&
Kwon, 2000). The procedure for calculation of zinc, calcium, phytate and phytate: $\mathrm{Zn}$ molar ratio has been described previously (Kwun \& Kwon, 2000). Nutrient intakes were compared with the Korean Recommended Dietary Allowance (Korean Nutrition Society, 2000).

\section{Blood sampling and processing}

A fasted blood sample was collected from subjects in the early morning, and plasma, erythrocytes and MNC were separated by layering the blood sample on to Histopaque 1077 (Sigma Aldrich, St Louis, MO, USA), and centrifuging at $400 \mathrm{~g}$ for $30 \mathrm{~min}$. Plasma was removed and frozen at $-80^{\circ} \mathrm{C}$ while the $\mathrm{MNC}$ at the Histopaque interface were removed and centrifuged at $250 \mathrm{~g}$ for $10 \mathrm{~min}$ to obtain a cell pellet. The pellet was washed with saline and the cells re-centrifuged and frozen at $-80^{\circ} \mathrm{C}$ in $1 \mathrm{ml}$ RNALater (Ambion, Austin, TX, USA).

\section{RNA isolation}

The MNC samples were defrosted on ice and centrifuged at $3000 \mathrm{~g}$ for $15 \mathrm{~min}$ at $4^{\circ} \mathrm{C}$ (MR 1822 Jouan centrifuge; ThermoElectron, Basingstoke, UK) in order to pellet them. The RNALater supernatant was discarded and RNA was extracted using TRIzol according to the instructions of the manufacturer (Invitrogen, Paisley, UK). The RNA pellet was briefly dried for 5-10 min and then dissolved in $10 \mu \mathrm{l}$ RNase-free water. Each sample was diluted $\times 1000$ and quantified by absorbance at $260 \mathrm{~nm}$ using an Eppendorf Biophotometer (Eppendorf UK Ltd, Cambridge, UK). The samples were stored at $-80^{\circ} \mathrm{C}$.

\section{cDNA synthesis by reverse transcription of RNA}

The RNA samples were diluted to a final concentration of $1 \mu \mathrm{g} / \mu \mathrm{l}$. A mastermix containing $2 \mu \mathrm{l} 10 \times$ concentrated RT buffer, $4.4 \mu \mathrm{l} 25 \mathrm{~mm}-\mathrm{MgCl}, 4 \mu \mathrm{l} 10 \mathrm{~mm}-\mathrm{DNTP}$ (with dTTP) and $1 \mu \mathrm{l} 50 \mu \mathrm{M}$-random hexamers was prepared by mixing, and $0.4 \mu \mathrm{l}$ RNase inhibitor (20 units/ $\mu \mathrm{l}$ ) and $1 \mu \mathrm{l}$ Multiscribe RT (50 units/ $\mu \mathrm{l}$ ) (Applied Biosystems, Warrington, UK) were subsequently added, also with mixing. To obtain a $20 \mu \mathrm{l}$ reaction mix, $5 \mu \mathrm{l}$ RNA sample and $2 \cdot 2 \mu \mathrm{l}$ water were added to $12.8 \mu \mathrm{l}$ of the mastermix. The reaction mixes were put into a thermal cycler (Hybaid Omn-E, Ashford, UK) and were heated at $30^{\circ} \mathrm{C}$ for $10 \mathrm{~min}$, then at $48^{\circ} \mathrm{C}$ for $30 \mathrm{~min}$ and finally at $95^{\circ} \mathrm{C}$ for $5 \mathrm{~min}$. The samples were frozen at $-80^{\circ} \mathrm{C}$ until required for the human MT-2A PCR.

\section{Real-time PCR for human metallothionein-2A}

After reverse transcription, MT-2A cDNA was amplified by realtime PCR using the TaqMan system (Applied Biosystems). PCR reaction mixes were prepared in a PCR workstation and reagents were dispensed using positive-displacement pipettes with autoclaved, UV-irradiated tubes and tips. cDNA samples were defrosted in ice and a premix of $50 \mu \mathrm{l} /$ tube of TaqMan Universal Master Mix (Applied Biosystems), $35 \mu \mathrm{l}$ RNA-free water and $6 \mu \mathrm{l}$ and $3 \mu \mathrm{l} /$ tube MT-2A for the forward-reverse primers and probe, respectively, were prepared. The purified primers were obtained from MWG-Biotech AG (London, UK) and the probe from Applied Biosystems. The sequences of the probes and primers for MT-2A were: 
Table 1. Age, zinc intake, plasma zinc and mononuclear cell MT-2A mRNA (MT mRNA) in subjects according to rural locality (see p. 248) and gender. Zinc intake is also expressed as a proportion of lean body mass $(\mathrm{Zn} / \mathrm{LBM})$, as a molar ratio with dietary phytic acid (Phy:Zn) and as a molar ratio index with dietary calcium and phytic acid (Phy $x \mathrm{Ca}: \mathrm{Zn})+$

(Mean values with their standard errors)

\begin{tabular}{|c|c|c|c|c|c|c|c|c|c|c|c|c|c|c|c|c|c|c|c|c|c|c|}
\hline \multirow[b]{2}{*}{ Rural locality } & \multirow[b]{2}{*}{ Sex } & \multirow[b]{2}{*}{$n$} & \multicolumn{2}{|c|}{ Age } & \multicolumn{2}{|c|}{$\begin{array}{l}\text { Energy intake } \\
\qquad(\mathrm{kJ} / \mathrm{d})\end{array}$} & \multicolumn{2}{|c|}{$\begin{array}{l}\text { Protein intake } \\
\qquad(\mathrm{g} / \mathrm{d})\end{array}$} & \multicolumn{2}{|c|}{$\begin{array}{l}\text { Protein intake } \\
\text { (\% animal } \\
\text { protein) }\end{array}$} & \multicolumn{2}{|c|}{$\begin{array}{l}\text { Zn intake } \\
(\mathrm{mg} / \mathrm{d})\end{array}$} & \multicolumn{2}{|c|}{ Zn:LBM ratio } & \multicolumn{2}{|c|}{$\begin{array}{l}\text { Phytate: } Z n \\
\text { ratio }\end{array}$} & \multicolumn{2}{|c|}{$\begin{array}{l}\text { Phytate } \times \\
\text { Ca:Zn ratio }\end{array}$} & \multicolumn{2}{|c|}{$\begin{array}{l}\text { Plasma Zn } \\
\qquad(\mu \mathrm{m})\end{array}$} & \multicolumn{2}{|c|}{ MT mRNA } \\
\hline & & & Mean & SE & Mean & SE & Mean & SE & Mean & SE & Mean & SE & Mean & SE & Mean & SE & Mean & SE & Mean & SE & Mean & SE \\
\hline 1 & M & 9 & $60 \cdot 2$ & $2 \cdot 2$ & 6879 & 2638 & $60 \cdot 1$ & $23 \cdot 0$ & $30 \cdot 5$ & 9.9 & $8 \cdot 4$ & 1.4 & $2 \cdot 78$ & 0.46 & 21.4 & $2 \cdot 7$ & $256 \cdot 1$ & 46.5 & 14.4 & $1 \cdot 1$ & 0.47 & 0.21 \\
\hline 1 & $\mathrm{~F}$ & 9 & $59 \cdot 1$ & 1.7 & 6649 & 883 & $53 \cdot 0$ & $10 \cdot 3$ & $20 \cdot 1$ & $6 \cdot 7$ & $6 \cdot 6$ & 0.6 & $2 \cdot 68$ & $0 \cdot 17$ & $22 \cdot 2$ & 3.7 & $198 \cdot 2$ & $57 \cdot 2$ & $11 \cdot 7$ & 0.9 & 0.49 & 0.31 \\
\hline 2 & M & 7 & $67 \cdot 7$ & $2 \cdot 4$ & 6875 & 657 & 54.4 & $7 \cdot 1$ & $24 \cdot 6$ & $9 \cdot 7$ & $6 \cdot 2$ & 0.4 & $2 \cdot 10$ & 0.2 & $27 \cdot 3$ & $5 \cdot 2$ & $412 \cdot 1$ & $142 \cdot 3$ & 14.9 & 1.5 & 0.27 & 0.08 \\
\hline 2 & $\mathrm{~F}$ & 9 & $65 \cdot 8$ & $2 \cdot 0$ & 5673 & 1034 & $41 \cdot 1$ & $10 \cdot 0$ & 14.4 & 8.6 & $6 \cdot 0$ & 0.7 & $2 \cdot 60$ & 0.33 & $19 \cdot 3$ & $1 \cdot 6$ & $143 \cdot 2$ & 33.2 & $15 \cdot 2$ & 0.7 & 0.47 & 0.16 \\
\hline 3 & M & 5 & $59 \cdot 4$ & $2 \cdot 8$ & 6033 & 636 & $46 \cdot 6$ & $11 \cdot 0$ & $23 \cdot 3$ & $9 \cdot 2$ & $7 \cdot 6$ & 0.9 & $2 \cdot 48$ & 0.27 & 21.9 & $3 \cdot 8$ & 235.9 & 88.5 & $14 \cdot 6$ & 0.7 & 1.05 & 0.45 \\
\hline 3 & $\mathrm{~F}$ & 4 & $56 \cdot 8$ & $3 \cdot 1$ & 7336 & 1833 & $69 \cdot 0$ & $19 \cdot 6$ & $17 \cdot 3$ & 20.9 & $8 \cdot 7$ & $1 \cdot 7$ & $3 \cdot 23$ & 0.54 & $13 \cdot 2$ & $1 \cdot 8$ & $112 \cdot 8$ & 11.9 & $10 \cdot 8$ & 0.3 & 0.59 & 0.31 \\
\hline 4 & M & 12 & 61.4 & $1 \cdot 8$ & 6628 & 997 & $57 \cdot 2$ & $15 \cdot 0$ & $27 \cdot 2$ & $12 \cdot 3$ & $7 \cdot 6$ & 0.9 & 2.39 & 0.28 & $24 \cdot 1$ & 1.9 & $256 \cdot 7$ & 45.9 & $11 \cdot 1$ & 0.9 & 0.71 & 0.19 \\
\hline 4 & $\mathrm{~F}$ & 10 & $62 \cdot 7$ & $2 \cdot 2$ & 6050 & 1445 & 51.0 & $15 \cdot 7$ & $23 \cdot 0$ & 7.9 & $6 \cdot 0$ & 0.6 & 2.47 & 0.25 & $28 \cdot 1$ & $3 \cdot 1$ & $259 \cdot 0$ & 52.3 & $9 \cdot 6$ & 0.8 & 1.9 & 0.50 \\
\hline 5 & M & 4 & $59 \cdot 3$ & $2 \cdot 4$ & 6100 & 406 & $48 \cdot 4$ & $6 \cdot 3$ & $24 \cdot 1$ & 9.9 & $6 \cdot 4$ & 1.9 & $2 \cdot 19$ & 0.49 & $26 \cdot 0$ & 2.5 & 192.6 & 33.5 & 11.9 & 0.7 & 1.07 & 0.42 \\
\hline 5 & $\mathrm{~F}$ & 8 & 63.9 & 2.5 & 6029 & 1097 & $47 \cdot 0$ & $13 \cdot 2$ & $19 \cdot 2$ & $11 \cdot 0$ & $7 \cdot 0$ & 1.5 & 2.85 & 0.65 & $19 \cdot 4$ & $2 \cdot 5$ & $143 \cdot 8$ & $40 \cdot 4$ & 11.4 & 1.0 & 1.47 & 0.66 \\
\hline 6 & M & 8 & 63.9 & 3.3 & 7055 & 1189 & $55 \cdot 7$ & 11.6 & $20 \cdot 3$ & 9.4 & $5 \cdot 6$ & 0.5 & 1.76 & 0.15 & 29.4 & $1 \cdot 6$ & $244 \cdot 7$ & $53 \cdot 1$ & $10 \cdot 6$ & 0.9 & 1.41 & 0.33 \\
\hline 6 & $\mathrm{~F}$ & 15 & $60 \cdot 7$ & $1 \cdot 8$ & 6214 & 1859 & $56 \cdot 4$ & 22.5 & $26 \cdot 5$ & $15 \cdot 0$ & $6 \cdot 7$ & 1.0 & $2 \cdot 84$ & 0.41 & $26 \cdot 1$ & 2.5 & $260 \cdot 2$ & 36.6 & $10 \cdot 5$ & 0.8 & $2 \cdot 41$ & 0.45 \\
\hline 7 & $\mathrm{M}$ & 6 & $63 \cdot 7$ & 2.4 & 6155 & 896 & $46 \cdot 8$ & $11 \cdot 7$ & $18 \cdot 8$ & $11 \cdot 8$ & $6 \cdot 6$ & 0.5 & $2 \cdot 14$ & 0.19 & $23 \cdot 2$ & $2 \cdot 1$ & 371.1 & 60.5 & $12 \cdot 6$ & 0.8 & $2 \cdot 13$ & 1.48 \\
\hline 7 & $\mathrm{~F}$ & 4 & $65 \cdot 8$ & 2.5 & 6084 & 988 & $48 \cdot 6$ & $12 \cdot 4$ & $17 \cdot 6$ & 9.1 & $5 \cdot 2$ & 0.4 & 2.53 & 0.26 & $26 \cdot 5$ & $2 \cdot 1$ & $226 \cdot 1$ & 50.0 & $13 \cdot 6$ & 1.8 & ND & \\
\hline All & $\mathrm{M}$ & 51 & 62.4 & 1.0 & 6649 & 1428 & $54 \cdot 8$ & $14 \cdot 7$ & $25 \cdot 4$ & 10.4 & $7 \cdot 0$ & 0.4 & $2 \cdot 29$ & 0.13 & $24 \cdot 7$ & $1 \cdot 1$ & 282.4 & $27 \cdot 7$ & $12 \cdot 7$ & 0.4 & 0.85 & 0.13 \\
\hline All & $\mathrm{F}$ & 59 & $62 \cdot 1$ & 0.9 & 6184 & 1369 & $51 \cdot 3$ & $16 \cdot 5$ & $21 \cdot 2$ & $11 \cdot 3$ & 6.5 & 0.4 & $2 \cdot 72^{*}$ & 0.15 & $23 \cdot 1$ & $1 \cdot 2$ & $204 \cdot 6$ & 18.3 & $11 \cdot 6$ & 0.4 & $1.33^{\star}$ & 0.21 \\
\hline All & All & 110 & $62 \cdot 2$ & 0.6 & 6364 & 1403 & $52 \cdot 6$ & $15 \cdot 9$ & $22 \cdot 8$ & $11 \cdot 1$ & $6 \cdot 8$ & 0.3 & 2.53 & 0.10 & $23 \cdot 8$ & 0.8 & $240 \cdot 7$ & 16.5 & $12 \cdot 1$ & 0.3 & $1 \cdot 10$ & 0.13 \\
\hline
\end{tabular}

F, female; LBM, lean body mass; M, male; MT, metallothionein; ND, not determined

* Statistical significance $(P \leq 0.05)$ when comparing males and females for all localities.

$\dagger$ For details of procedures, see pages 248 and 250 . 
Forward primer: 5'-GCA CCT CCT GCA AGA AAA GC-3' Reverse primer: $5^{\prime}$-TGG AAG TCG CGT TCT TTA CAT CT- $3^{\prime}$

Probe: 5'-FAM-CTC CTG CTG CCC TGT GGG CTG TTAMRA-3'

A single PCR product of 154 bp was consistently obtained, with no evidence of genomic DNA amplification, which would yield a product of $359 \mathrm{bp}$. 18S ribosomal RNA (TaqMan Ribosomal RNA Control Reagents VIC Probe Protocol; Applied Biosystems) was used as a reference.

In each plate one non-template control and seven standards were run with the samples. Since the objective was to measure relative rather than absolute concentrations, standards were made by diluting a selected sample, according to the protocols supplied by Applied Biosystems. The concentration of reverse-transcribed RNA in the top standard was $250 \mathrm{ng} / \mu \mathrm{l}$, and six serial dilutions were made to give the following additional standard concentrations: $62 \cdot 5,15 \cdot 62,3 \cdot 9,0.97,0 \cdot 24$ and $0.04 \mathrm{ng} / \mu \mathrm{l}$; and for $18 \mathrm{~S}$ : 10, 2.5, 0.625, 0.156, 0.039, 0.010 and $0.003 \mathrm{ng} / \mu \mathrm{l}$. The samples were diluted to $50 \mathrm{ng} / \mu \mathrm{l}$. To each microcentrifuge tube, $51.8 \mu \mathrm{l}$ premix and $2.2 \mu \mathrm{l}$ of water, standards or sample cDNA were added. The tubes were vortexed and then centrifuged for $1 \mathrm{~min}$ at high speed using a Sigma 1-13 centrifuge. Then $2 \times 25 \mu \mathrm{l}$ of control, standards and samples were dispensed into duplicate wells of a PCR ninety-six-well plate. To remove any bubbles in the wells, the plate was sealed and centrifuged for $1 \mathrm{~min}$ in a Sigma 3-15 centrifuge. The plate was then analysed for target transcript levels by real-time PCR using an Applied Biosystems PRISM 7700 instrument. Standard operating conditions of $50^{\circ} \mathrm{C}$ for $2 \mathrm{~min}$ (for Uracil $\mathrm{N}$-glycosylase activity), $95^{\circ} \mathrm{C}$ for $10 \mathrm{~min}$ (for hot-start taq polymerase activation) and forty cycles of $95^{\circ} \mathrm{C}$ for $15 \mathrm{~s}$ (denaturation) and $60^{\circ} \mathrm{C}$ for $1 \mathrm{~min}$ (annealing and extension) were used.

\section{Additional blood analyses}

Blood haematocrit was measured by the microhaematocrit method using heparinized capillary tubes and a dedicated centrifuge. $\mathrm{Hb}$, plasma protein, albumin, glucose and HDL were measured using commercial assay kits (Asan Pharmaceuticals, Seoul, South Korea), and LDL was calculated using the Friedwald formula. Plasma thiobarbituric acid reactive substances were determined by the method of Yagi (1984) and plasma $\alpha$-tocopherol was measured by the method of Bieri et al. (1979) using reversed-phase HPLC (Shimadzu Corporation, Kyoto, Japan). Plasma zinc was determined on duplicate samples using atomic absorption spectrophotometry (Solaar SP9, Unicam, UK) after 5-fold dilution with $0 \cdot 1 \mathrm{M}-\mathrm{HCl}$ and centrifugation. The accuracy of zinc determination was verified by frequent analysis of a standard reference material (Trace Elements, Serum Level 1; Seronorm, Sero, Norway) which was prepared by dissolving the freeze-dried powder in ultrapure water, as instructed and diluting 5-fold with $0 \cdot 1 \mathrm{M}-\mathrm{HCl}$ followed by centrifugation. Plasma homocysteine levels were analysed by an isotope dilution GC-MS technique (Calder et al. 1999).

\section{Statistical analysis}

A correlation-based principal component analysis was performed on the study variables and the relationship between the variables was then visualized in a corresponding bi-plot
(Fig. 4). Correlations were calculated using the Pearson correlation coefficient. For the multiple regression analysis, a stepwise regression method was used to find the appropriate model. The 'Stepwise' procedure of the computer program S-Plus 2000 (1999, MathSoft Inc., Cambridge, MA, USA) which is based on the Efroyson-algorithm (Miller, 1979), was used with default settings.

\section{Results}

\section{Zinc intake}

The mean zinc intake for males and females in all rural localities studied was estimated to be 7.0 and $6.5 \mathrm{mg} / \mathrm{d}$, respectively (Table 1). However, when corrected for lean body mass, zinc intake was significantly higher in females than males (Table 1). The range of zinc intake was very wide, being $1.7-20.6 \mathrm{mg} / \mathrm{d}$, although over $75 \%$ of all subjects had an intake of between 4 and $8 \mathrm{mg} / \mathrm{d}$ (Fig. 1). The phytate: $\mathrm{Zn}$ ratio was in excess of 20 , and the phytate $\times \mathrm{Ca}: \mathrm{Zn}$ ratio was in excess of 200 for most localities (Table 1).

\section{Plasma zinc and mononuclear cell metallothionein-2A mRNA}

As with zinc intake, plasma zinc showed a wide variation ranging from 6.5 to $20.4 \mu \mathrm{M}$ (Fig. 2). The overall mean for 110 subjects was $12 \cdot 1 \mu \mathrm{M}$, with males having slightly higher levels $(12.7 \mu \mathrm{M})$ than females $(11.6 \mu \mathrm{M})$. The levels of MNC MT-2A mRNA were $1 \cdot 5$-fold higher in females than in males $(P=0 \cdot 05)$. There was considerable locality-related variation in MT-2A mRNA levels (Table 1) and they tended to increase with age for both male and female subjects, although this trend was not statistically significant (Fig. 3(A)). There was a significant negative association between MT-2A mRNA and plasma zinc (Fig. 3(B)).

\section{Principal component analysis}

Figure 4 shows the bi-plot of the principal component analysis of all the study variables and highlights and summarizes all interactions in one figure, including those mentioned earlier. Notable positive associations were between plasma zinc and

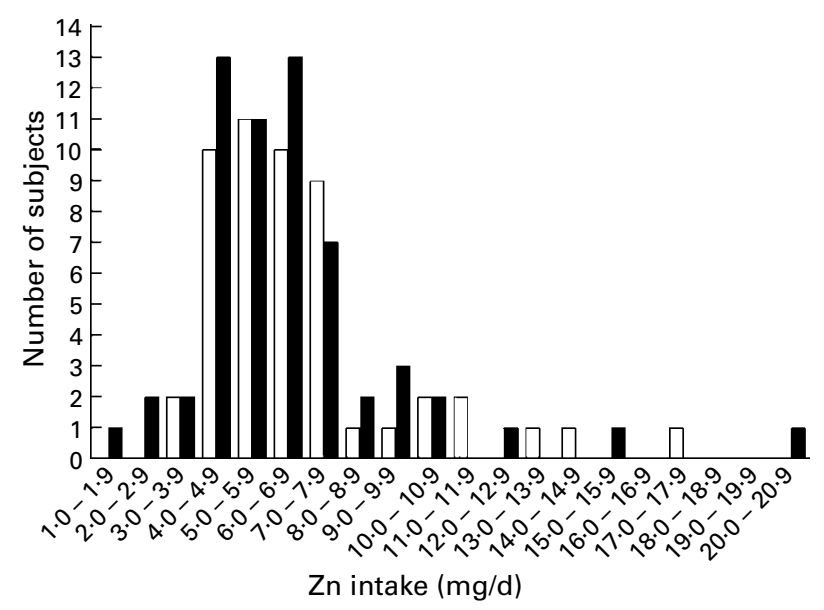

Fig. 1. Zinc intake frequency distribution profile of volunteers ( $\square$, males; females) from all localities. For details of procedures, see p. 248. 


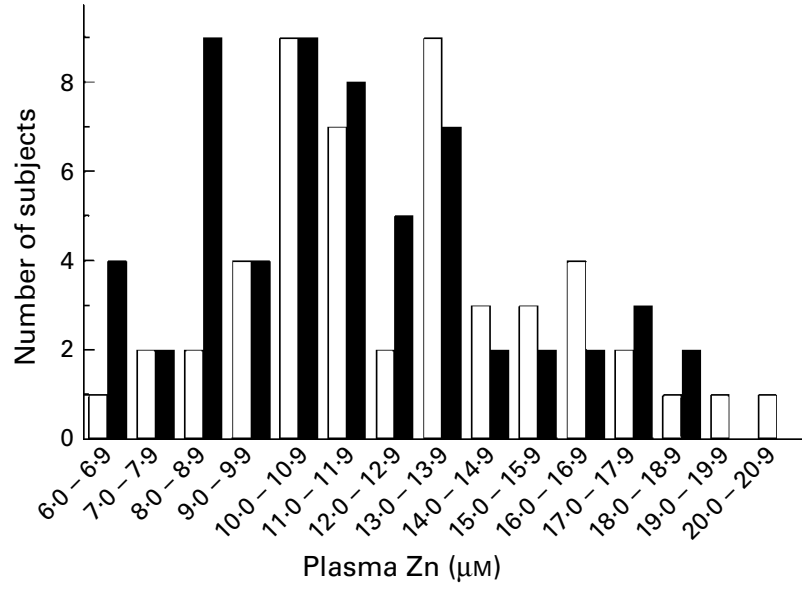

Fig. 2. Plasma zinc frequency distribution profile of volunteers ( $\square$, males; females) from all localities. For details of procedures, see p. 250.

plasma glucose, and dietary zinc intake and plasma glucose. Negative associations included dietary zinc intake and phytate: $\mathrm{Zn}$ ratio. A highly significant positive correlation ( $R 0.53, P<0.001)$ between dietary zinc intake and phytate intake was observed (data not shown).

\section{Multiple regression analysis}

In the multiple regression analysis, the influence of all measured variables on the variation in plasma zinc and MNC MT mRNA levels was evaluated. The most influential of these variables are shown in Table 2 in order of decreasing statistical significance. In the case of plasma zinc, the most influential variable was the serum albumin level, and in the case of MNC MT-2A mRNA it was the plasma zinc level.

\section{Discussion}

Dietary zinc intake by rural Koreans is known to be below what is considered adequate, and the risks of zinc deficiency are compounded by high dietary intake of phytic acid and a low intake of animal protein (Kwun \& Kwon, 2000). Phytate is a tenacious chelator of zinc and reduces zinc absorption (Lo et al. 1981; Krebs, 2000; Lonnerdal, 2000) and high molar ratios of phytate: $\mathrm{Zn}$ in human populations have been associated with zinc deficiency (Ruz et al. 1991). In the present study, phytate:Zn molar ratios were $>15$ in all but one locality, indicating low zinc absorption (Hotz et al. 2003). Dietary zinc intake (mean intake of 7.0 and $6.5 \mathrm{mg} \mathrm{Zn} / \mathrm{d}$ for males and females, respectively) was considerably lower than in metropolitan Korean localities (about $11 \mathrm{mg}$ Zn/d; Kwun \& Kwon, 2000; Lee et al. 2004) and also in western countries such as the UK (mean intake of 10.2 and $7.4 \mathrm{mg} \mathrm{Zn/d}$ for males and females, respectively) (Henderson et al. 2003). Phytic acid intake showed a very significant positive correlation with zinc intake because they both tend to be found in the same foods, particularly grain, soyabean and its products, all of which are common constituents of Korean diets. However, principal component analysis indicated a negative correlation between phytate/zinc and zinc intake, suggesting that the ratio of phytate to zinc was higher at low zinc intake. This would indicate that individuals most at risk of zinc deficiency through low consumption of
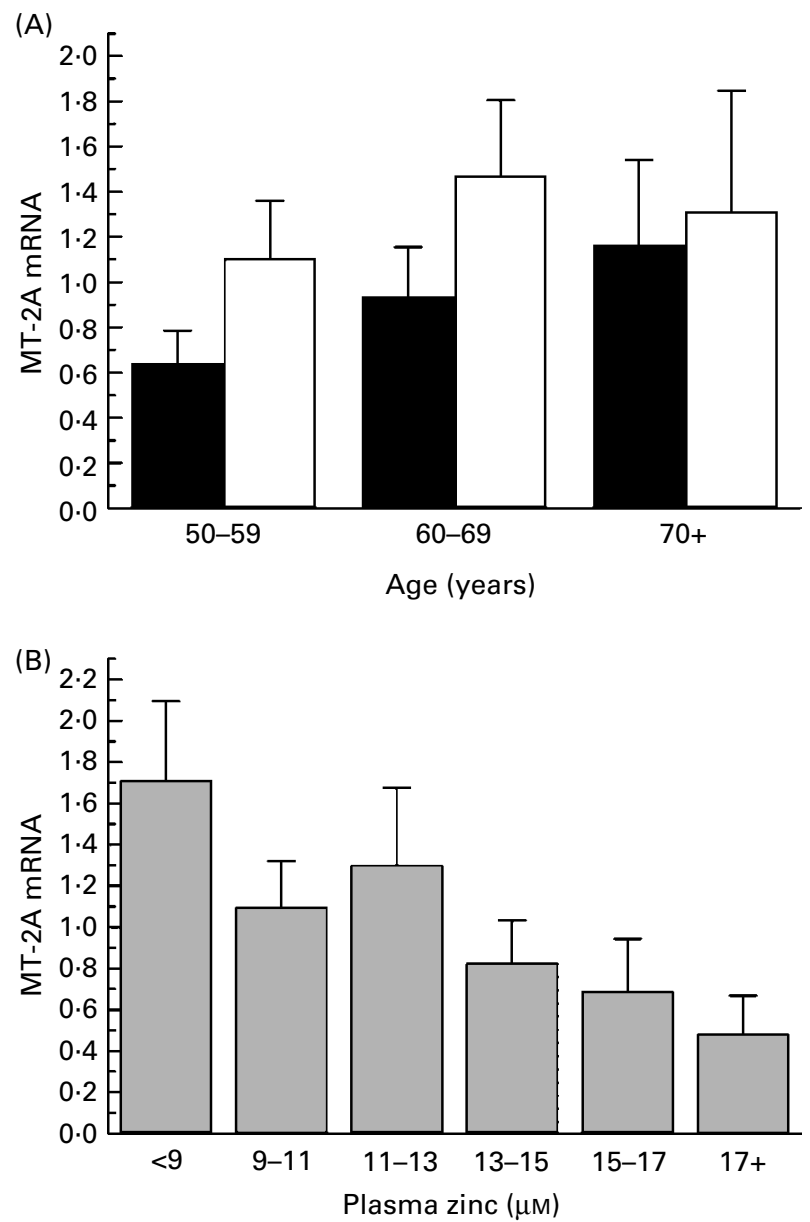

Fig. 3. Levels of mononuclear cell (MNC) metallothionein-2A (MT-2A) mRNA related to volunteer age (A; $\boldsymbol{\square}$, males; $\square$, females) and plasma zinc (B). For details of procedures, see pp 248 and 250 . Values are means with their standard errors depicted by vertical bars. Regression of plasma zinc with MNC MT-2A mRNA gave a correlation coefficient $(R)$ of $-0.296(P=0.004)$ but there was no significant correlation of MT-2A mRNA with age $(P=0.111)$.

zinc may be at even higher risk due to poor zinc absorption efficiency. Calcium is also a dietary antagonist of zinc absorption and a high index, calculated from multiplying molar levels of calcium $\times$ phytate and dividing by zinc, may induce zinc deficiency (Ruz et al. 1991). The significance of calcium influences on zinc absorption, particularly in view of its binding affinity for phytic acid and the potential to compete with zinc binding, remains controversial (Lonnerdal, 2000). Subjects in most Korean localities had a phytate $\times \mathrm{Ca}: \mathrm{Zn}$ index of $>200$, with some individuals having an index of 500-1000. Once again, individuals with a lower zinc intake tended to consume a higher proportion of $\mathrm{Ca}: \mathrm{Zn}$ and phytate:Zn. On the basis of previous evaluations of dietary zinc intake and the impact of absorption inhibitors (Krebs, 2000; Lonnerdal, 2000), it seems likely that most of the subjects recruited for the present study were zinc deficient. Unfortunately, there are no reliable markers of zinc status, but previous studies have demonstrated that rural Koreans have significantly lower levels of plasma alkaline phosphatase, a zinc-dependent enzyme, than found in urban Koreans (Lee et al. 2004).

Plasma zinc levels were not significantly related to dietary zinc intake, whether expressed as $\mathrm{mg} \mathrm{Zn} / \mathrm{d}$ or as a ratio with 


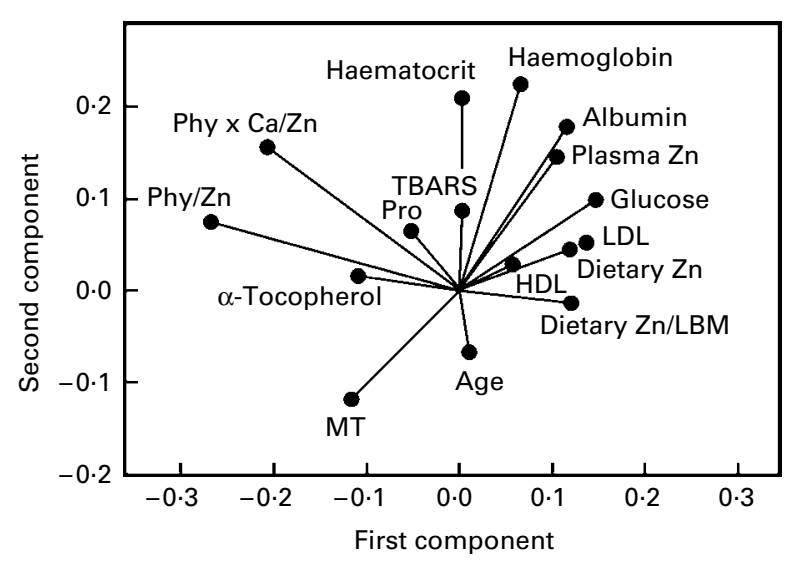

Fig. 4. Principal component analysis of study variables. The central point from which all lines radiate represents a score of zero for both principal components. Lines radiating in a similar direction are made by variables that show positive associations whereas those radiating in opposite directions are made by variables that are negatively correlated. For example, mononuclear cell metallothionein-2 mRNA (MT) is negatively correlated with plasma $\mathrm{Zn}$ (Fig. 3(B)). Glucose refers to plasma glucose. LBM, lean body mass; Phy, dietary phytate intake; Pro, plasma total protein; TBARS, plasma thiobarbituric acid reactive substances.

phytate and/or calcium, and were similar to those reported previously for Korean adults (Paik et al. 1999; Andree et al. 2004; Lee et al. 2004). Since it is highly likely that some of the subjects in the present study were zinc deficient and others were zinc adequate, the lack of responsiveness of plasma zinc to varying zinc status is consistent with the current consensus of opinion (Wood, 2000; Hambidge, 2003). The multiple regression analysis indicated that plasma zinc was most influenced by serum albumin levels, followed by blood $\mathrm{Hb}$, blood glucose and HDL. The variables identified by the analysis accounted for only $31 \%$ of the variance in the plasma zinc data, and so other unaccounted for influences were also present. The positive association of plasma zinc with serum albumin could relate to the role of this protein in zinc transport, but considering that albumin is present in considerable molar excess to the bound zinc, an explanation based on simple binding capacity is not credible. The positive association of plasma zinc with blood $\mathrm{Hb}$ was also quite strong, and a positive association between $\mathrm{Hb}$ and haematocrit was also apparent from the principal component analysis. This suggests that erythrocyte counts may be reduced when plasma zinc is low, and the observation that chronically zinc-deficient mice become anaemic due to an attenuation of erythropoesis (King et al. 2005) would seem to support this hypothesis. Anaemia has previously been associated with zinc deficiency but has been attributed to concomitant high dietary phytate intake, which also inhibits iron absorption. The positive relationship between blood glucose and plasma zinc is contrary to what might be expected from the known inverse relationship between these variables (Sondergaard et al. 2006). Zinc stimulates insulin secretion (Huber \& Gershoff, 1973) and receptor activation (Haase \& Maret, 2003) which facilitates glucose uptake by cells and elicits a decrease in blood glucose levels. Acute zinc deficiency is reported to reduce circulating levels of homocysteine in rats (Hong et al. 2000) but there was no evidence for any association between plasma homocysteine and either dietary zinc intake, plasma zinc or MNC MT mRNA levels (data not shown).

The strongest association of MNC MT-2A mRNA levels was with plasma zinc levels, but it should be noted that the negative correlation, which was highly significant for male and female data collectively $(P=0 \cdot 004)$, was much more significant in women $(P=0.02)$ than in men $(P=0 \cdot 22)$ (data not shown). The inverse relationship could be explained in several different ways. Since zinc stimulates MT gene expression, a higher plasma level of zinc may be expected to promote an increase in MT mRNA within cells directly exposed to blood plasma. However, in the long term, the presence of adequate MT protein levels may feed back to down-regulate gene expression. Alternatively, stress factors or the presence of inflammatory cytokines may stimulate MT expression in tissues including MNC and the liver, which would promote transfer of zinc from the plasma into the tissues. This is a well-characterized response of plasma zinc to stress (Shenkin, 1995) and is absent in MTdeficient mice (Rofe et al. 1996). Another possible explanation is an influence of zinc on MNC composition. Lymphocytes, monocytes and granulocytes express different levels of MT (Kimura, 1991; Aydemir et al. 2006) and a zinc-related change in the proportion of cell type may affect apparent MT gene expression. A suppressive effect of zinc deficiency on lymphopoiesis and the reverse effect on myelopoiesis has been

Table 2. Factors which were most influential on the variation in plasma zinc and mononuclear cell MT-2A mRNA, determined using stepwise multiple correlation. Explanatory variables are listed according to their significance and $R^{2}$ indicates how much of the response variation is explained by these factors $\left(100 \%\right.$ when $\left.R^{2}=1\right) \dagger$

\begin{tabular}{|c|c|c|c|c|c|}
\hline Response variable & Explanatory variable & Value & SE & $t$ & $P$ \\
\hline \multirow[t]{6}{*}{ Plasma zinc $\left(R^{2} 0.308\right)$} & Albumin & 1.6831 & 0.5606 & 3.0023 & 0.0034 \\
\hline & $\mathrm{Hb}$ & 0.5241 & 0.1876 & $2 \cdot 7937$ & 0.0062 \\
\hline & Glucose & 0.0259 & 0.0103 & 2.5078 & 0.0137 \\
\hline & $\mathrm{HDL}$ & -0.076 & 0.031 & -2.4373 & 0.0165 \\
\hline & $\alpha$-Tocopherol & -0.064 & 0.0325 & -1.9565 & 0.0531 \\
\hline & Intercept & 0.3478 & 3.0737 & 0.1132 & 0.9101 \\
\hline \multirow{7}{*}{ Metallothionein-2A mRNA $\left(R^{2}\right.$ 0.249) } & Plasma Zn & -0.101 & 0.0383 & -2.6257 & 0.0103 \\
\hline & LDL & -0.008 & 0.0037 & -2.236 & 0.028 \\
\hline & Protein & 0.4081 & 0.1993 & 2.0473 & 0.0437 \\
\hline & Age & 0.0353 & 0.0178 & 1.9814 & 0.0508 \\
\hline & $\alpha$-Tocopherol & 0.0236 & 0.0143 & 1.6447 & 0.1037 \\
\hline & Haematocrit & -0.039 & 0.025 & -1.5754 & 0.1189 \\
\hline & Intercept & -0.413 & 2.018 & -0.2045 & 0.8385 \\
\hline
\end{tabular}

†For details of procedures, see p. 250. 
reported (Fraker \& King, 2004). However, given the wide differences in MT expression that we observed and the predominance of lymphocytes in MNC fractions, it seems unlikely that a change in the proportion of cell type could entirely explain the relationship between MT mRNA and plasma zinc. However, in the present study, it was impracticable to either separate the different cell types or quantify their numbers, so we are unable to discount this possibility.

A weak negative correlation $(R-0 \cdot 192)$ between MNC MT2A mRNA and plasma LDL was not statistically significant at the $5 \%$ level $(P=0 \cdot 067)$. However, by multiple regression, LDL was a significant contributory variable influencing the variance of MNC MT-2A mRNA levels $(P=0.028)$. This apparent relationship requires further study for confirmation.

Of particular interest were the significantly higher levels of MNC MT-2A mRNA in women compared to men and the age-related increase in MT expression. The latter relationship was not statistically significant but age was identified as a significant factor influencing MT-2A mRNA levels from the stepwise multiple regression analysis and is worthy of further study. If MT expression were only dependent on plasma zinc, then very little age-related change in MT levels might be expected. However, blood levels of cytokines such as IL-6, which are also known inducers of MT (Schroeder \& Cousins, 1990), increase with age (Krabbe et al. 2004) and it is likely that the age-related increase in MT expression seen in the present study is a consequence of increased inflammatory stress and/or medication in the elderly. As a consequence, plasma zinc levels might be expected to decrease with age, but this was not the case in the present study. There was no significant correlation between age and plasma zinc $(P=0.464)$.

In conclusion, many of the rural Korean subjects recruited for the present study were likely to be zinc deficient according to their low dietary zinc intake and high intake of zinc absorption inhibitors. Plasma zinc was within the normal range for adults and was unrelated to age or gender while MNC MT2A mRNA showed a weak age-related increase and also higher levels in female subjects. A stronger inverse relationship between MT mRNA levels and plasma zinc might indicate that induction of MT in MNC by an unidentified factor, such as inflammatory cytokines, could favour transfer of zinc from the plasma to the tissues. MT mRNA levels did not correlate with any measure of dietary zinc intake, and so either the latter is a poor predictor of zinc status or MNC expression of MT-2A cannot be used as a diagnostic indicator of zinc status in free-living older human subjects.

\section{Acknowledgements}

J. H. B., A. M. K. and C. M. were funded by the Scottish Executive Environment and Rural Affairs Department. C. S. K. was supported by a grant from the Korean Science and Engineering Foundation (grant number F01-2004-000$10277-0)$. I. S. K. was supported by the Korean Ministry of Health and Welfare (grant number 03-PJ1-PG3-22 000-0038).

\section{References}

Allan AK, Hawksworth GM, Woodhouse LR, Sutherland B, King JC \& Beattie JH (2000) Lymphocyte metallothionein mRNA responds to marginal zinc intake in human volunteers. $B r J$ Nutr 84, $747-756$

Andree KB, Kim J, Kirschke CP, Gregg JP, Paik H, Joung H, Woodhouse L, King JC \& Huang L (2004) Investigation of lymphocyte gene expression for use as biomarkers for zinc status in humans. J Nutr 134, 1716-1723.

Aydemir TB, Blanchard RK \& Cousins RJ (2006) Zinc supplementation of young men alters metallothionein, zinc transporter, and cytokine gene expression in leukocyte populations. Proc Natl Acad Sci USA 103, 1699-1704.

Bieri JG, Tolliver TJ \& Catignani GL (1979) Simultaneous determination of alpha-tocopherol and retinol in plasma or red cells by high pressure liquid chromatography. Am J Clin Nutr 32, 2143-2149.

Calder GM, Garden KE, Anderson SE \& Lobley GE (1999) Quantitation of blood and plasma amino acids using isotope dilution electron impact gas chromatography/mass spectrometry with U-(13)C amino acids as internal standards. Rapid Commun Mass Spectrom 13, 2080-2083.

Cao J \& Cousins RJ (2000) Metallothionein mRNA in monocytes and peripheral blood mononuclear cells and in cells from dried blood spots increases after zinc supplementation of men. J Nutr 130, 2180-2187.

Fraker PJ \& King LE (2004) Reprogramming of the immune system during zinc deficiency. Аnпи Rev Nutr 24, 277-298.

Grider A, Bailey LB \& Cousins RJ (1990) Erythrocyte metallothionein as an index of zinc status in humans. Proc Natl Acad Sci USA 87, 1259-1262.

Haase H \& Maret W (2003) Intracellular zinc fluctuations modulate protein tyrosine phosphatase activity in insulin/insulin-like growth factor-1 signaling. Exp Cell Res 291, 289-298.

Hambidge M (2003) Biomarkers of trace mineral intake and status. J Nutr 133, Suppl. 3, 948S-955S.

Henderson L, Irving K, Gregory J, Bates CJ, Prentice A, Perks J, Swan G \& Farron M (2003) The National Diet \& Nutrition Survey: Adults Aged 19 to 64 Years; Vitamin and Mineral Intake and Urinary Analytes. London: HMSO.

Hong KH, Keen CL, Mizuno Y, Johnston KE \& Tamura T (2000) Effects of dietary zinc deficiency on homocysteine and folate metabolism in rats. $J$ Nutr Biochem 11, 165-169.

Hotz C, Lowe NM, Araya M \& Brown KH (2003) Assessment of the trace element status of individuals and populations: the example of zinc and copper. J Nutr 133, 1563S-1568S.

Huber AM \& Gershoff SN (1973) Effect of zinc deficiency in rats on insulin release from the pancreas. J Nutr 103, 1739-1744.

Kimura M (1991) Metallothioneins of monocytes and lymphocytes. Methods Enzymol 205, 291-302.

King JC (1990) Assessment of zinc status. J Nutr 120, Suppl. 11, $1474-1479$.

King LE, Frentzel JW, Mann JJ \& Fraker PJ (2005) Chronic zinc deficiency in mice disrupted $\mathrm{T}$ cell lymphopoiesis and erythropoiesis while B cell lymphopoiesis and myelopoiesis were maintained. J Am Coll Nutr 24, 494-502.

Korean Food and Drug Association (1996) Korean Food Composition Table, 1996. Seoul: Korean Food and Drug Association.

Korean Food and Drug Safety Section (2002) Korean Food Composition Table, 2002. Seoul: South Korean Ministry of Health and Welfare.

Korean Nutrition Society (2000) Korean Recommended Dietary Allowance, 7th ed. Seoul: Korean Nutrition Society.

Krabbe KS, Pedersen M \& Bruunsgaard H (2004) Inflammatory mediators in the elderly. Exp Gerontol 39, 687-699.

Krebs NF (2000) Overview of zinc absorption and excretion in the human gastrointestinal tract. J Nutr 130, 1374S-1377S.

Kwun IS \& Kwon CS (2000) Dietary molar ratios of phytate: zinc and millimolar ratios of phytate calcium: zinc in South Koreans. Biol Trace Elem Res 75, 29-41. 
Lee SL, Kwak EH, Yoon JS, Kwon CS, Beattie JH \& Kwun IS (2004) Zinc nutritional status in Korean adults from rural, urban and metropolitan areas. J Food Sci Nutr (Korea) 9, 174-182.

Lo GS, Settle SL, Steinke FH \& Hopkins DT (1981) Effect of phytate:zinc molar ratio and isolated soybean protein on zinc bioavailability. J Nutr 111, 2223-2235.

Lonnerdal B (2000) Dietary factors influencing zinc absorption. J Nutr 130, 1378S-1383S.

McKenzie JM (1979) Content of zinc in serum, urine, hair, and toenails of New Zealand adults. Am J Clin Nutr 32, 570-579.

Miller A (1979) Subset Selection in Regression. London: Chapman and Hall/CRC.

Paik HY, Joung H, Lee JY, Lee HK, King JC \& Keen CL (1999) Serum extracellular superoxide dismutase activity as an indicator of zinc status in humans. Biol Trace Elem Res 69, 45-57.

Robertson A, Morrison JN, Wood AM \& Bremner I (1989) Effects of iron deficiency on metallothionein-I concentrations in blood and tissues of rats. J Nutr 119, 439-445.

Rofe AM, Philcox JC \& Coyle P (1996) Trace metal, acute phase and metabolic response to endotoxin in metallothionein-null mice. Biochem J 314, 793-797.

Ruz M, Cavan KR, Bettger WJ, Thompson L, Berry M \& Gibson RS (1991) Development of a dietary model for the study of mild zinc deficiency in humans and evaluation of some biochemical and functional indices of zinc status. Am J Clin Nutr 53, 1295-1303.

Sato M, Mehra RK \& Bremner I (1984) Measurement of plasma metallothionein-I in the assessment of the zinc status of zincdeficient and stressed rats. J Nutr 114, 1683-1689.

Schroeder JJ \& Cousins RJ (1990) Interleukin 6 regulates metallothionein gene expression and zinc metabolism in hepatocyte monolayer cultures. Proc Natl Acad Sci USA 87, 3137-3141.

Shenkin A (1995) Trace elements and inflammatory response: implications for nutritional support. Nutrition 11, 100-105.

Sondergaard LG, Stoltenberg M, Doering P, Flyvbjerg A \& Rungby J (2006) Zinc ions in the endocrine and exocrine pancreas of zinc deficient rats. Histol Histopathol 21, 619-625.

Thomas EA, Bailey LB, Kauwell GA, Lee DY \& Cousins RJ (1992) Erythrocyte metallothionein response to dietary zinc in humans. J Nutr 122, 2408-2414.

World Health Organization (2002) Quantifying selected major risks to health. In The World Health Report 2002, pp. 47-97. Geneva: WHO.

Wood RJ (2000) Assessment of marginal zinc status in humans. J Nutr 130, 1350S-1354S.

Yagi K (1984) Assay for blood plasma or serum. Methods Enzymol 105, 328-331. 